\title{
The downshift of the electrical percolation threshold in polyisoprene-nanostructured carbon composites
}

Juris Zavickis,

\author{
Artis Linarts, \\ Maris Knite \\ Riga Technical University, \\ Institute of Technical Physics, \\ Azenes Str. 14-322, \\ LV-1007 Riga, Latvia \\ E-mail: juriszavickis@inbox.lv
}

In our previous research, the polyisoprene-nanostructured carbon composite (PNCC) has been approved as a promising material to be used as a low-pressure sensor. The main advantage of PNCC is its hyperelastic flexibility as compared with conventional piezo-ceramic pressure sensors as well as the outstanding sensitivity to small $(<1 \mathrm{Bar})$ pressures. The PNCC is elaborated by incorporating highly structured particles of a good conductor (Printex XE2 carbon black) and necessary curing ingredients into the raw elastomer matrix (Thick Pale Creppe natural polyisoprene) and subsequent vulcanization afterwards. One can find in literature that the final electric properties of the composite greatly depend on the mixing method used. In our work, we use an ultrasound source as an alternative method to disperse the nanostructured filler. Roll-mixed, mechanically mixed in solution and ultrasound-mixed in solution PNCC samples were made. Their critical electrical percolation concentrations were determined and critical indexes were calculated for all types of PNCCs using linear trendlines on log-log plots. The piezoresistive behaviour of such composites was evaluated and compared.

Key words: polyisoprene, natural rubber, carbon, nanostructured, composite, piezoresistivity

\section{INTRODUCTION}

\section{Prime novelty statement}

The emerging field of robotics and smart machinery keeps demanding new types of compressive and strain sensors. This requires new materials to be elaborated. Conventional pressure and strain sensors are solid structures causing certain difficulties when integrating them into a structure being monitored. Some filled elastomers are known to exhibit a pressure-sensitive behaviour [1-5]. Most current research promotes PNCC to be used as a prospective material for pressure sensing. At the conductive filler concentrations close to percolation, these composites show a magnificent reversible tensoresistive and piezoresistive effect [6]. In this work, we present PNCC to be used for flexible pressure sensor elaboration. We have successfully obtained a downshift of the electrical percolation threshold by using ultrasound processing for filler dispersing. We claim our research as an important achievement in developing a new kind of a smart composite material which could be used for pressure sensing in integrated structures.

\section{Previous research}

The mechano-electric active polymer composites have been obtained by dispersing electrically conductive particles (carbon black, graphite powder, carbon fibers or particles of metals) into a polymer matrix [1-6]. A gradual insulator-conductor transition is observed in such systems when increasing the fraction of randomly dispersed conductor particles. Such transitions, called percolation transitions, are described by the model of statistical percolation $[7,8]$. The volume concentration of the disperse phase $V_{C}$ at which the transition proceeds is called the percolation threshold, or the critical point [8].

In the vicinity of the percolation threshold, the specific electrical conductivity of the composite $\sigma$ changes according to

$$
\sigma \sim\left|V-V_{c}\right|^{t}, f V>V_{c}
$$

where $t$ is the non-universal critical index [8]. According to the concept of piezoresistivity, Knite et al. [9] have proposed that in the sharpest region of the percolation transition the 


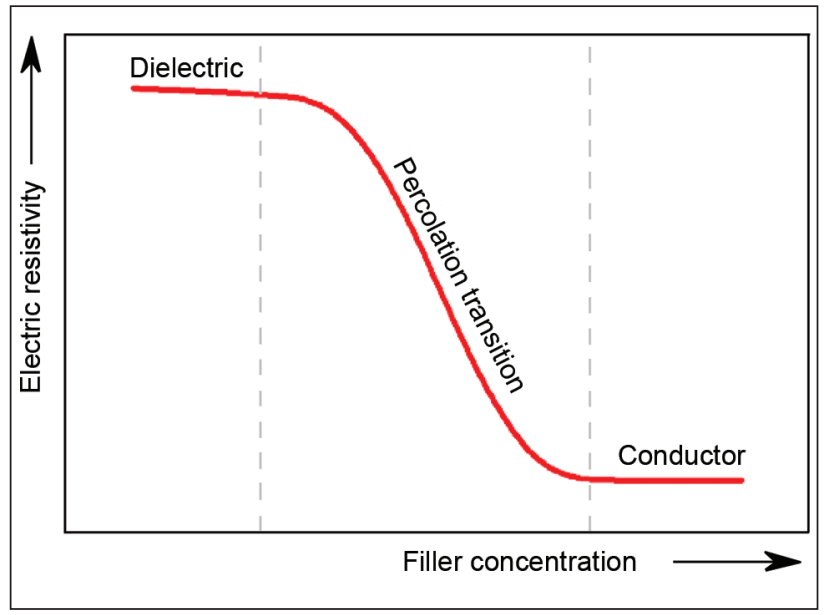

Fig. 1. The principle illustration of the percolation threshold for carbon-filled conductive composites

composite should be sensitive to an external mechanical action (the region of interest shown in Fig. 1). Additionally, we propose that the percolation threshold is expected to shift to a lower concentration region, if a more effective method is used for the dispersion of the conductive filler $[6,9]$.

\section{SAMPLES AND EXPERIMENTAL EQUIPMENT}

\section{Making the samples}

Polyisoprene-nanostructured carbon composite raw rubber was composed from Thick Pale Creppe polyisoprene natural rubber, the necessary curing ingredients and commercially available high-structure carbon black (HSCB). Degussa Printex Xe2 HSCB (average particle diameter $30 \mathrm{~nm}$, DBP absorption value $380 \mathrm{ml} / 100 \mathrm{~g}$ and a specific surface area of $950 \mathrm{~m}^{2} / \mathrm{g}$ ) were chosen as an electroconductive filler. The concentration of the conductive filler further in the article is given in "parts per hundred rubber". The current measurement method was adopted from rubber chemistry, later mentioned as p. h. r. in the text and figures, which means mass parts of filler per 100 mass parts of natural polyisoprene.

Three types of PNCC raw rubbers were prepared by different methods for dispersing the conductive filler:

1) roll-mixed PNCC was obtained by directly mixing all curing ingredients and HSCB into polyisoprene on cold rolls (Fig. 2);

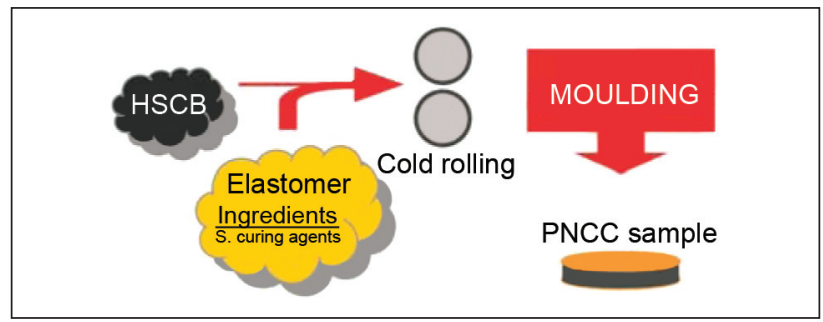

Fig. 2. Scheme of making a roll-mixed PNCC sample
2) chloroform solution mechanically mixed (further in the text - mechanically mixed) PNCC was made by first mixing the curing ingredients (except HSCB) into a polyisoprene matrix using cold rolls. The obtained raw rubber was dissolved in chloroform, and then a necessary amount of HSCB was added. The solution was homogenized by high-speed mechanical mixing with small glass beads for $30 \mathrm{~min}$. Then the solution was poured into a glass plate for chloroform to evaporate, and raw rubber films were obtained. The films were then homogenized using cold rolls with the smallest possible aperture (Fig. 3) to eliminate any filler concentration gradient possibly acquired when drying on a glass plate;

3) chloroform suspension ultrasound-mixed (further in the text - US-mixed) PNCC was made by first mixing the curing ingredients (except $\mathrm{HSCB}$ ) into a polyisoprene matrix, using cold rolls. The HSCB was dispersed separately in chloroform, using a Hielscher UP200S ultrasound homogenizer for 5 minutes. The specific power was $1 \mathrm{~W} / \mathrm{ml}$. Then, the filler dispersion in chloroform was added to the raw rubber / chloroform mixture and stirred at room temperature for $24 \mathrm{~h}$. Then the solution was poured into a glass plate for chloroform to evaporate, and raw rubber films were obtained. The acquired films were then homogenized using cold rolls with the smallest possible aperture (Fig. 4) to eliminate any filler gradient possibly acquired when drying on a glass plate.

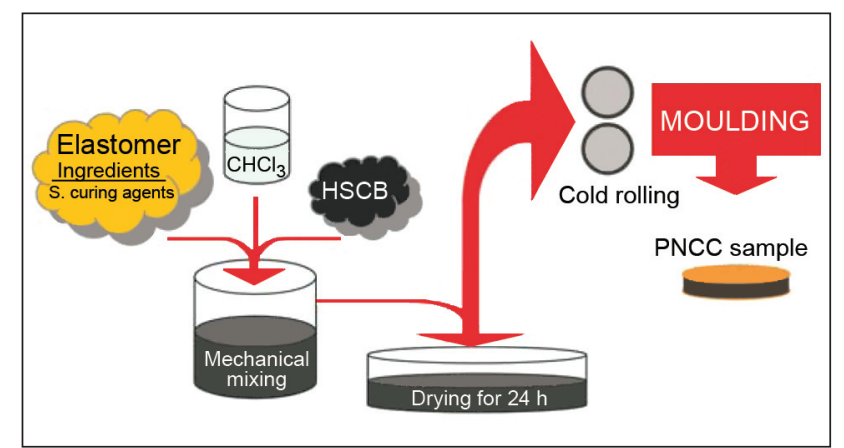

Fig. 3. Scheme of making a mechanically mixed PNCC sample

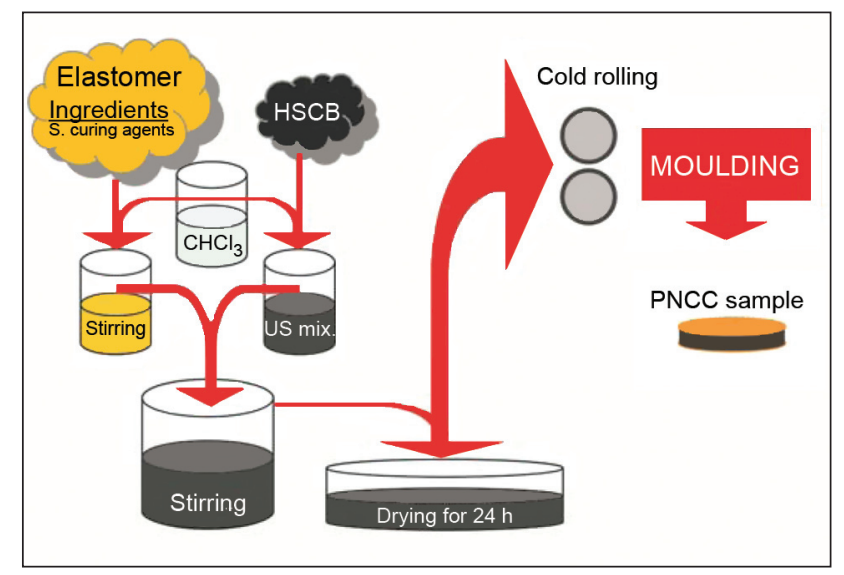

Fig. 4. Scheme of making a US-mixed PNCC sample 
Flat samples of the average thickness of $1 \mathrm{~mm}$ were made by vulcanizing raw rubber in a hot stainless steel mould using a Rondol ${ }^{\mathrm{Ts}}$ thermostated press at $150{ }^{\circ} \mathrm{C}$ for 15 to $20 \mathrm{~min}$. Brass foil mould inserts were used to acquire a good electrical connection for future electrical measurements.

The samples had been shelf-aged at room temperature for at least $24 \mathrm{~h}$ after processing before any electrical measurements were made.

\section{Instrumentation}

The optimal curing time was determined using a Monsanto dynamic rheometer.

The initial electrical resistivity of the samples was measured using an Agilent A34970A digital multimeter / multiplexer and a Keithley Model 6487 Picoammeter / Voltage source. The mechano-electrical testing was done using a Zwick / Roell Z2.5 universal material testing machine coupled and synchronized with the Agilent A34970A digital multimeter / multiplexer. The samples at lower regions of percolation thresholds were not measured for piezoresistivity, because the upper resistivity range of the dynamic measuring data logger was limited to $10^{8} \Omega$. The trend line fitting was done using the Origin8 data analysis and graphing software.

\section{RESULTS AND DISCUSSION}

The initial electrical resistivity of PNCC samples was measured first. Their electrical resistivity was plotted versus the conductive filler concentration, obtaining percolation transitions displayed in Fig. 5.

One can see in the figures that the percolation transition for roll-mixed and mechanically mixed PNCC is much steeper than for US-mixed PNCC, so theoretically we could expect them to show a much better piezoresistive behaviour. The experimental data were carefully fitted by statistical percolation theory which predicted the dependence of
Fig. 5. Specific electrical conductivity versus filler fraction for differently prepared PNCCs and their critical concentrations $\varnothing$

Fig. 6. Linear fitting of the conductive part of the $\log \sigma$ versus $\log (\phi-\Phi)$ plot for differently prepared PNCCs
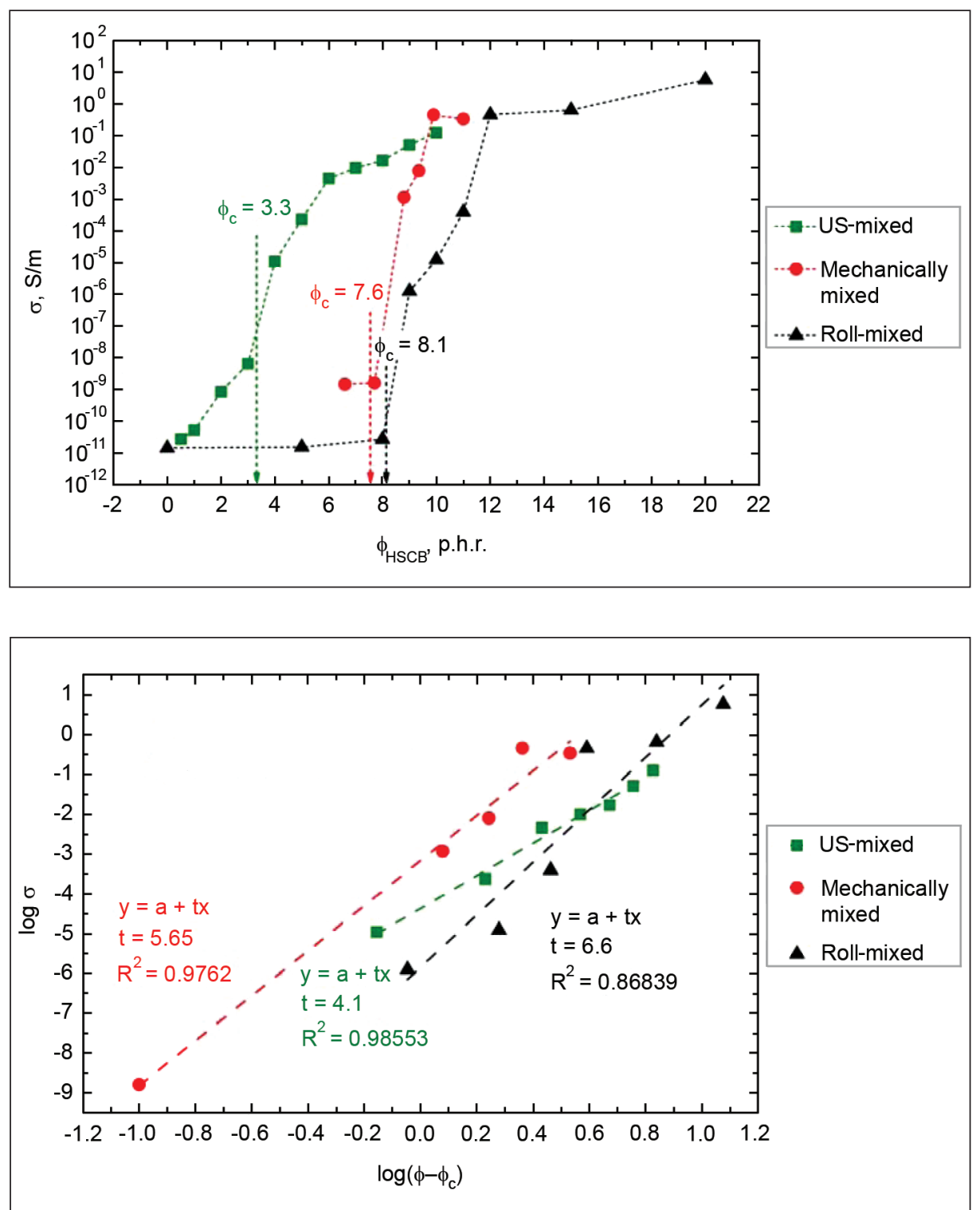
conductivity on filler concentration (the so-called "scaling law"):

$$
\sigma=\sigma 0\left(\Phi-\Phi_{c}\right)^{t}
$$

The critical concentrations $\left(\Phi_{c}\right)$ of the corresponding percolation thresholds were found (Fig. 5) by plotting the experimental $\log \sigma$ versus $\log \left(\Phi-\Phi_{c}\right)$ (Fig. 6) by the same way of incrementally varying $\Phi_{c}$ until the best linear fit was reached [10].

As is seen in the corresponding figures, the mechanical mixing with glass beads in chloroform solution instead of roll mixing doesn't contribute to lowering the percolation threshold. In contrast, the sonication of a conductive filler in chloroform suspension helped to reduce the percolation threshold as much as 2.5 times. According to Kilbride et al. [10], the slope of the linear trend line in Fig. 6 corresponds to the critical index $t$. According to Yakubowicz et al. [11], the critical index $t$ can be interpreted as the average number of simultaneous ohmic contacts of each conductive filler particle with its neighbours. Thus, the critical index indirectly describes the complexity of the conductive grid. According to these assumptions, the larger $t$, the sharper the percolation transition should be. The sharpness of the percolation transitions in Fig. 5 correlates quite well with the values of critical indices obtained in Fig. 6. This proves that proper sonication reduces the complexity of the HSCB structure, possibly resulting in a more uniform distribution of HSCB aggregates. According to theory, the better distribution of filler particles should lead to a noticeable increase of tunneling currents. Bauhofer suggests [12] that the intensity of tunneling currents between closely distributed but non-touching conductive particles can be described by the following expression:

$$
\ln \sigma_{D C} \propto \Phi^{-\frac{1}{3}} \text {. }
$$

When plotting the conductive part of the percolation threshold as $\log \sigma$ versus $\Phi^{-1 / 3}$, the coefficient of determination $R^{2}$ of its linear fit is proportional to the contribution of tunneling currents to the conductivity of PNCCs (Fig. 7).

The piezoresistive response $\left(\Delta R / R_{0}, \%\right)$ of roll- and USmixed PNCC samples was determined (Fig. 8) using the unidimensional pressure $P$ up to 1 bar. Similar measurements on mechanically mixed PNCC were unavailable because of the lack of samples with proper dimensions.

By analyzing the piezoresistivity, we can see that in rollmixed PNCCs the piezoresistivity greatly depends on HSCB concentration. The maximal piezoresistivity for mechanically mixed PNCCs is found in the lower concentration end of percolation transition ( $8 \mathrm{p}$. h. r. on the black curve in Fig. 5). At the same time, the maximal piezoresistivity for US-mixed PNCCs is found in the upper concentration region of percolation transition (6 p. h. r. on the red curve in Fig. 5).

These differences can be explained as follows. According to the literature, inter-particle slippage occurs during mechanical deformation due to excessive share forces, and electro-conductive channels are partly destroyed. As a result, we obtain positive piezoresistivity. The conducting channels in roll-mixed PNCCs are generally formed by larger HSCB agglomerates. For this reason, we observe a higher piezoresistivity at the lower concentration region of percolation transition, where the additional shunting of conductive channels is limited due to the low filler concentration. At a higher filler concentration, the shunting of conductive channels increases, thus reducing the overall piezoresistivity of a PNCC. On the contrary, the conducting channels in US-mixed PNCC are formed by well distributed smaller HSCB primary particles which exhibit a better mobility as compared to aggregates, thus a more complete conductive grid breakdown can be achieved even with large fractions of a filler.

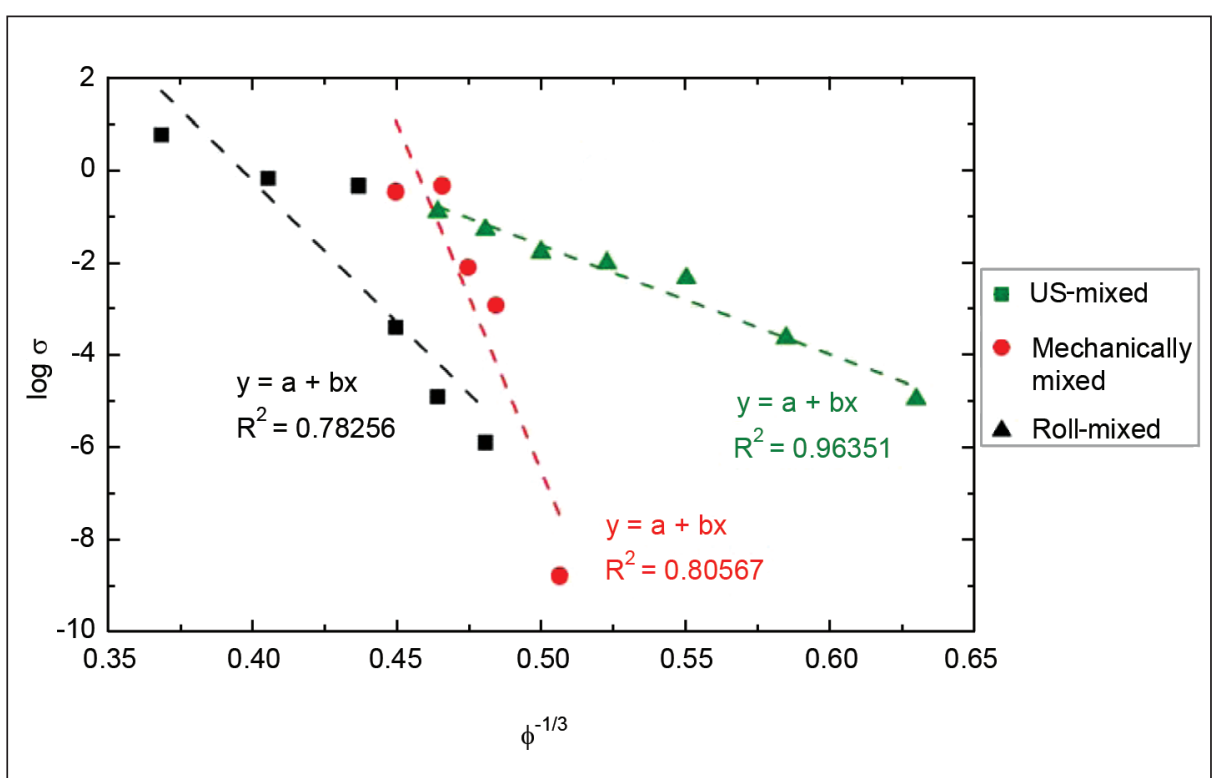

Fig. 7. The linear fit of the log $\sigma$ versus $\Phi^{-1 / 3}$ plot for differently prepared PNCCS 


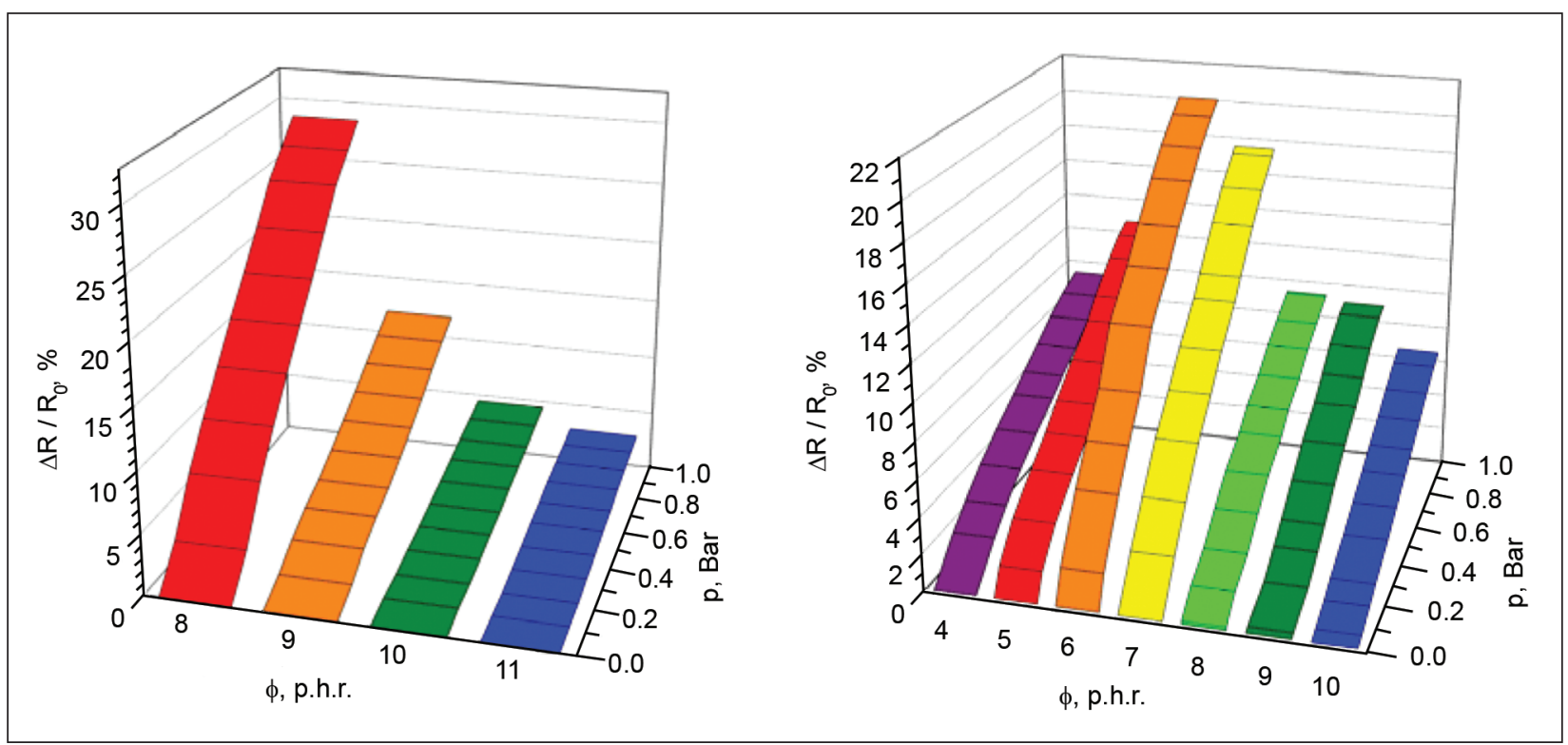

Fig. 8. The piezoresistive behaviour of roll- (left figure) and US-mixed (right figure) PNCCS

\section{CONCLUSIONS}

The slope and position of the percolation transition for PNCCs depends on the mixing method used to disperse HSCB. The implementation of sonication in the mixing process allowed to decrease the percolation threshold up to 2.5 times, at the same time reducing the overall sharpness of the whole percolation transition. A correlation was found between the critical index of percolation, the sharpness of percolation transition and the maximum piezoresisitivity of PNCCs. The ultrasound dispersal of HSCB in a suspension, instead of direct roll or mechanical mixing in solution, reduces the structure of the conductive filler, evidenced by increasing the relevance of tunneling currents and shifting the percolation threshold to the region of the lower concentration. The maximal change of electrical resistivity for roll-mixed PNCCs can reach up to $30 \%$ under a uni-dimensional pressure of 1 bar. The maximal piezoresistive sensitivity shifts from the lower concentration region of percolation transition for roll-mixed PNCCs up to the higher concentration region for US-mixed PNCCs. The main reason could be the increased mobility of smaller and better distributed HSCB particles.

\section{ACKNOWLEDGEMENTS}

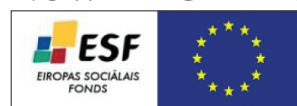

The research was supported by the Council of Science of Latvia and by the Latvian National Research Program in Materials Science, as well as by the European Social Fund within the project "Support for the implementation of doctoral studies at Riga Technical University".

\section{References}

1. Aneli J. N., Zaikov G. E., Khananashvili I. M. Effects of mechanical deformations on the structurization and electric conductivity of electric conducting polymer composites. Journal of Applied Polymer Science. 1999. No. 74. P. 601621.

2. Zhang X. W., Pan Y., Zheng Q., Yi X. S. Time dependence of piezoresistance for conductor-filled polymer composites. Journal of Polymer Science. B: Polymer Physics. 2000. Vol. 38. P. 2739-2749.

3. Das N. C., Chaki T. K., Khastgir D. Effect of axial stretching on electrical resistivity of short carbon fibre and carbon black filled conductive rubber composite. Polymer International. 2002. Vol. 51. P. 156-163.

4. Wu T. M., Cheng J. C. Morphology and electric properties of carbon black-filled poly(e-caprolactone)/poly(vinyl butyral) nanocomposites. Journal of Applied Polymer Science. 2003. Vol. 88. P. 1022-1031.

5. Wu T. M., Yan M. C., Cheng J. C. Thermoelectric properties and morphology of carbon black-filled poly(e-caprolactone)/poly(vinyl butyral)/clay nanocomposites. Polymer. 2003. Vol. 44. No. 8. P. 2553-2562.

6. Knite M., Teteris V., Polyakov B., Erts D. Electric and elastic properties of conductive polymeric nanocomposites on macro- and nanoscales. Material Science and Engineering: C. 2002. Vol. 19. No. 2. P. 15-19.

7. Staufer D., Aharony A. Introduction into Percolation Theory. Washington DC: Taylor \& Francis, 1992. 198 p.

8. Balberg I. A comprehensive picture of the electrical phenomena in carbon black-polymer composites. Carbon. 2002. Vol. 40. P. 139-143.

9. Knite M., Teteris V., Kiploka A., Kaupuzs J. Polyisoprenecarbon black nanocomposites as tensile strain and pressure sensor materials. Sensors and Actuators. A: Physical. 2004. Vol. 110. No. 1-3. P. 142-149. 
10. Kilbride B. E., Coleman J. N., Fraysse J., Fournet P., Cadek M., Drudy A. Experimental observation of scaling laws for alternating current and direct current conductivity in polymer-carbon nanotube composite thin films. Journal of Applied Physics. 2002. Vol. 92. No. 7. P. 4024-4030.

11. Jacubowicz J., Narkis M. Dielectric behavior of carbon black filled polymer composites. Polymer Engineering and Science. 1986. Vol. 26. No. 22. P. 1568-1573.

12. Bauhofer W., Kovacs Z. A review and analysis of electrical percolation in carbon nanotube polymer composites. Computer Science and Technology. 2009. Vol. 69. No. 10. P. 1486-1498.

Juris Zavickis, Artis Linarts, Maris Knite

\section{ELEKTRINIO PERKOLIACIJOS SLENKSČIO MAŽINI- MAS POLIIZOPRENO-NANO STRUKTŪROS ANGLIES MIŠINYJE}

Santrauka

Ankstesni tyrimai patvirtino, kad poliizopreno-nano struktūros anglies mišinys (PNAM, angl. polyisoprene-nanostructured carbon composite, PNCC) yra perspektyvi medžiaga, tinkama žemam slègiui atpažinti. Lyginant su ịprastais, pjezokeraminiais slègio jutikliais, pagrindinis PNAM pranašumas - hiperelastinis lankstumas bei itin didelis jautrumas mažam slègiui ( $<1$ bar). PNAM yra sudaromas ị neapdorotos elastomerų matricos (storas blyškiai natūralus poliizoprenas kaučiukas (angl. thick pale creppe natural polyisoprene) sudètị ịtraukiant itin struktūrizuotas gero laidininko daleles (Printex XE2 juodoji anglis) ir būtinus apsaugančius ingredientus ir vèliau vulkanizuojant. Anot literatūros šaltinių, galutinès elektrinès mišinio savybès labai priklauso nuo taikomo maišymo metodo. Šiame darbe ultragarso šaltinis naudojamas kaip alternatyvus būdas išsklaidyti nano struktūros užpildą. Buvo sukurti PNAM pavyzdžiai valcuojant, mechaniškai maišant tirpale ir ultragarsu maišant tirpale. Buvo ịvertintos ir palygintos šių mišinių pjezovaržos savybès.

Raktažodžiai: poliizoprenas, natūrali guma, anglis, nano struktūros, mišinys, pjezovarža
Юрис Завицкис, Артис Линартс, Марис Кните

\section{СНИЖЕНИЕ ПОРОГА ЭЛЕКТРОПЕРКОЛЯЦИИ В СМЕСИ НАНО-СТРУКТУРЫ ПОЛИИЗОПРЕНА И УГЛЯ}

Pез юме

Исследованиями подтверждено, что смесь нано-структуры полиизопрена и угля (NAM, англ. polyisoprene-nanostructured carbon composite) является перспективным материалом в определении низких давлений. По сравнению с обычными пьезокерамическими датчиками давления главным преимуществом являются гиперэластичность и высокая чувствительность к низким давлениям (<1 бар). PNAM создается в процессе внедрения в состав необработанной матрицы эластомеров высокоструктурированных частиц электропроводника (XE2 черный уголь) и необходимых защитных ингредиентов в процессе последующей вулканизации. Отмечается, что заключительные электрические свойства сильно зависят от метода перемешивания - в данной работе использован ультразвуковой источник в качестве альтернативного метода для рассредоточения нано-структурного заполнителя. Созданы образцы PNAM в процессе вальцовки при механическом перемешивании в растворах. Представлены оценка и сопоставление пьезосопротивления всех смесей.

Ключевые слова: полиизопрен, уголь, нано-структуры, смеси, пьезосопротивление 